\title{
ARE RELIGIOUS BELIEVERS IRRATIONAL: A DIRECT TEST FROM AN EFFICIENT MARKET HYPOTHESIS
}

\section{Chamil W. Senarathne}

Wuhan University of Technology, Wuhan, China

e-mail: chamil@whut.edu.cn

ORCID: 0000-0002-4813-0213

\section{(C) 2020 Chamil W. Senarathne}

This is an open access article distributed under the Creative Commons Attribution-NonCommercial-NoDerivs license (http://creativecommons.org/licenses/by-nc-nd/3.0/)

DOI: $10.15611 /$ fins.2020.1.04

JEL Classification: G12, G14, I31, N30, Z12, Z13

\begin{abstract}
The current literature does not offer a quantitative test of the irrational behaviour of people, especially taking a proxy for irrationality with reference to an economic activity. This paper examines the role of religious believers in carrying out economic activities. The form of stock market efficiency has been taken as a proxy for testing the null hypothesis that religious believers are irrational on average. The findings suggest that equity markets in religious countries are inefficient at 'weak form' level. This provides prima facie evidence for the hypothesis that religious believers are irrational on average. As such, the equity price changes of these stock markets can be forecast on the basis of past patterns. Poor income level and education are the main causes for developing irrationality. As these irrationalities cost economies, the policymakers should design and implement more robust policies and guidelines for poverty alleviation and the enrichment of education at country level.
\end{abstract}

Keywords: religion, believers, efficient market hypothesis (EMH), atheists, irrationality, education.

\section{Introduction}

My expectations were reduced to zero when I was 21. Everything since then has been a bonus [Hawking 2004]. By nature, human beings tend to form expectations about the future in day-to-day life and human actions are then incidentally directed towards achieving such expectations in the course of living. If they are realized as expected, the happiness occurs but with no incremental benefits (i.e. payoffs) at the time of realization because they have prevailed at the time of expectation. To understand this from an academic perspective, read the life lesson thesis of Bachelier [1900] in which he put forward the idea that alert speculators receive nothing from the past prices. Hence, a speculator will not benefit from tracing past records (or patterns) of security price movements. Another valuable explanation was given by Keynes [1937], according to whom (paragraph three), everything in this world 
is certainly uncertain and the best way to face this uncertainty is to be rational in decision-making. What causes one's intention to be rational is the irrationality of thinking rooted in the existing beliefs of people about the universal truth. There is only one truth in this world and people look at this truth from different perspectives through different Gods. This does not mean that those who believe in God are irrational, but the way of forming expectations is merely on the basis of faith, without a logical reasoning (throughout this paper, God is referred to as any gods people believe in and is plural for the purpose of respect). A contrasting view is that there should not necessarily be any reasoning for religious beliefs [Audi 1991]. People look at this truth from different perspectives through different faiths but the common phenomenon of all faiths is belief. No matter which God people believe in, the way of forming expectations about what God will give as sought is the same. That is to say, religious people tend to think that God will give what they expect as a right, although this is not the case (see e.g. [Scudder 1897]). God certainly knows one's future, which is unknown to mankind, and He plans for seekers of good, according to His will, for the enduring good, and not based on what is sought from Him (see more: [Bible in One Year 2017]). God will give what people seek at His will, but timing is unknown to the seekers (see e.g. Matthew 7:7 and many others). Hence, people cannot form expectations based upon past actions or past experience. If this is interpreted with reference to finance and economics, forming expectations based upon past records or a pattern does not make sense. Let these believers be called rational believers (henceforth, the terms "rational believers" and "speculators" or "speculative traders" are used interchangeably) who form no expectations about future economic outcome based upon past actions taken towards achieving the expected outcome, but they believe that God will give what they seek according to His will (see [Brams 1979]). People with this trait do not rely on the past actions and their records when making economic decisions because the timing of future outcome is uncertain, hence they cannot form expectations with a probable outcome. Rational believers as economic agents (in the course of engaging in economic activities) believe in the present and have 'time zero unbounded' (uncertain timing and amounts) expectations about the inflows or outflows of future activities embodying economic benefits (cost). When interpreted with reference to economics, these economic agents make decisions on the basis of information available at that time and their expectations of inflows or outflows of future economic benefits (cost) are zero. Those of contrary view are the irrational believers who simply believe that God will give them what is sought and tend to form expectations on the basis of past actions (traced from past records) taken towards achieving the expected outcome. These believers find a close association between the past and future in economic decision-making, for example, making an investment in the hope of a defined profit, after a careful analysis of the past records of performance. For instance, the classic work by Block and Kramer [2009] shows that economic agents with superstitious beliefs tend to make irrational economic decisions, whereas those who do not, adhere to a more rational choice 
paradigm. Why do people have unique preferences for some temples or churches? It is because they have superstitious beliefs about visiting or making a vow over other places, as past experience suggests. The following figure shows the distribution of the atheist population of the world.

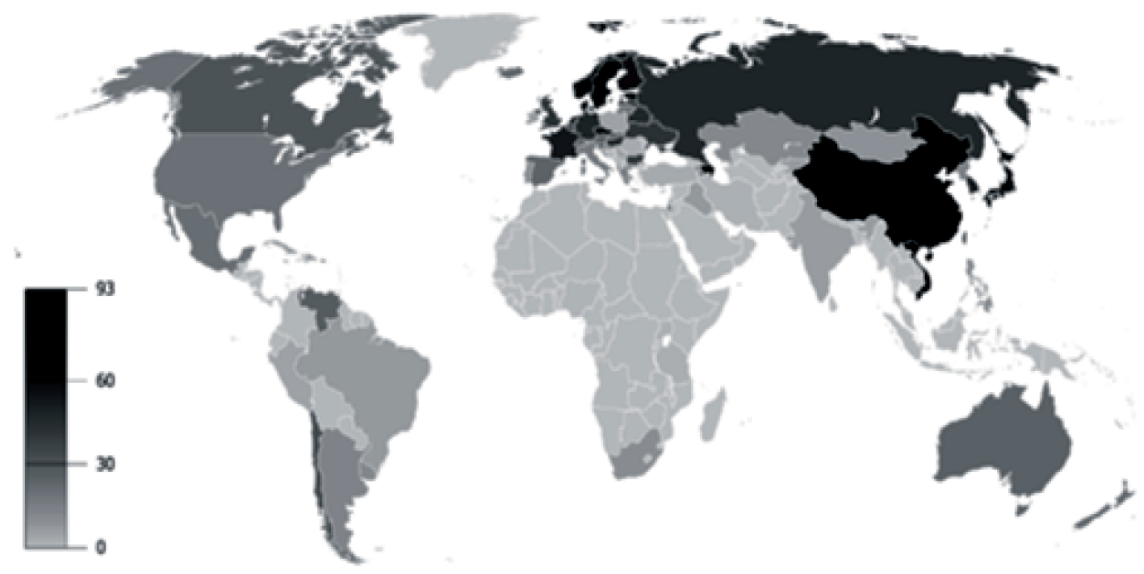

Fig. 1. World Non-Religious Population (Percentage)

Source: World non-religious population (percentage), Dentsu Institute [2006] and Zuckerman [2005].

In Figure 1, the score ranges from 0 - 100 where the darkest-colour regions are most irreligious. Considerable parts of Canada, the United States, Europe and most parts of China, Australia and New Zealand are predominately atheist.

Scholars comment that internal religious orientation helps reduce the psychological problems in medical treatments (e.g. [Homayouni 2011]). Moltafet et al. [2010] investigate the relationship between personality traits and happiness with religious orientation as a mediator and find that religious orientation mediates the relationship between personality traits and happiness. Behavioural traits are strongly linked to religiosity. The recent work by Khoynezhad et al. (2012) show that religious beliefs have an impact on personality traits such as neuroticism, extraversion, openness, agreeableness and conscientiousness. The behavioural traits of managers influence different aspects of business management (see e.g. [McDaniel and Burnett 1990; Jamal and Badawi 1993; Weaver and Agle 2002; Vitell and Paolillo 2003; Grullon et al. 2009; McGuire et al. 2011; Schneider et al. 2011]). It is therefore highly likely that these traits will be reflected in every economic decision that people make (e.g. stock trading).

The objective of this paper is to examine whether the religious population are irrational on average, taking stock market efficiency/inefficiency as a proxy for rationality/irrationality. The paper is organized as follows. Section 2 discusses EMH and religiosity and formulates the hypothesis of the study. Section 3 reviews root 
causes of irrational behaviour and documents the linkage between poverty and education and its implications for such behavior. Section 4 provides an extensive literature review on testing for EMH compared with Global Index of Religiosity. Section 5 provides the concluding remarks.

\section{Efficient Market Hypothesis (EMH) and religiosity}

EMH hypothesis is built upon logic and rationality. Malkiel [2003] quotes the famous joke to explain rationality with respect to the concept of EMH, in the sense that, "A well-known story tells of a finance professor and a student who come across a $\$ 100$ bill lying on the ground. As the student stops to pick it up, the professor says, don't bother - if it were really a $\$ 100$ bill, it wouldn't be there". Hence, EMH calls into question one's inquiring mind (i.e. rationality) with regard to stock market investment. The theory suggests that the stock prices fully reflect all available information at any given point in time and, as such, no arbitrage opportunities are available in the market for stock traders, therefore the present is the future for those who believe in EMH. No one could the see potential benefits from either purchasing undervalued stocks or selling overvalued stocks. Since the seminal paper by Fama [1965], a number of scholars have attempted to test the validity of EMH in different jurisdictions. The classic work by Basu [1977] on the analysis of the P/E ratio as an indication of future investment performance of a security (without relaxing any of those assumptions of EMH), shows a clear deviation from the efficient market hypothesis. On the other hand, behaviourists in this sector of finance then began to argue to the contrary. They showed that irrational human behaviour is not independent from equity price changes (see e.g. [Malkiel 1985; 1995; 2003; Shiller 2000]). Some symptoms of market irrationality have been reported by a number of scholars, for example, positive feedback trading [De Long et al. 1990] and herding [Trueman 1994; Chang et al. 2000].

Except for a handful of indirect scholarly work (e.g. [Wilson 1975; Shiller et al. 1984; Iannaccone 1997]), the direct linkage between religiosity and EMH has not been documented in the literature. Without linking religiosity to EMH, these scholars study other aspects of social dynamics and stock prices. The recent work by Blau [2017] found that religiosity is negatively related to the volatility of stock prices and attempted to link the risk-taking behaviour to religiosity, arguing that businesses in more religious countries are less likely to take risk in the course of their operations and business decision-making. Blau [2018] examined the linkage between religiosity and liquidity in financial markets, and found that religiosity directly influences the liquidity of securities and results in improved liquidity. Alawadhi [2016] showed that non-Islamic institutional investors tend to hold more lottery-type stocks than Islamic institutional investors and attribute such differences in traits to their religious norms. This implies that the irreligious (those who do not adhere to any religious norms) investors tend to understand the randomness of stock price changes. 


\subsection{Theoretical specification}

Assume a world with insignificant differences among religions in terms of religious norms. On the assumption that religiosity of an economic agent impacts his/her economic decisions (i.e. investment decisions), define $\delta_{s t}$ the payoffs attributable to a rational believer from trading in any equity of $s^{\text {th }}$ intraday trade carried out in the market so that, at the end of each trading day, a speculator satisfies with $p_{i t}-p_{i t-1}=\sum_{s=1}^{n_{t}} \delta_{s t}$ amount of stochastic payoffs collected at $n$ amount of observations (i.e. operations) in each day in the market for price increments $\left(p_{i t}-p_{i t-1}\right)>0$ given information set $I$ available at time $t$. The conditional price increments are stationary, stochastic and an increasing function of operation $t$ observed by $n$ because this market is efficient (as explained under Section 1, the trades carried out by rational believers results in stochastic payoffs). If a trader attempts to ascertain his/ her payoffs from trading in the market, the following model could be used in the sense of Black [1972]. This version of return modeling is more robust and empirically testified for its efficient application by a number of scholars (see e.g. [Banz 1981]).

$$
r_{i t}=\beta_{0}+\beta_{m} r_{m t}+\varepsilon_{t},
$$

where $r_{m t}$ is the return on market portfolio at time $t$ and $\varepsilon_{t}$ is payoffs attributable (stochastic noise) to a speculative trader on stochastic information events observed at each operational time $t$ in the market (note that payoffs $\varepsilon_{t}$ is under direct control of the individual firms) and $\beta_{0}+\beta_{m} r_{m t}$ is the mean of return (this is the arbitrage component of return in inefficient stock markets as functional form of efficiency suggests) conditional on information set $I$ available to investors at time $t$.

On the assumption of homoscedasticity of residuals, $E\left(\varepsilon_{t} \mid r_{m t}\right)=0$. Since the market is assumed to be efficient, $E\left(\varepsilon_{t} \mid n_{t}\right) \geq 0$ where $n_{t}$ is the operation $n$ at time $t$. At each operation directed by observation $n$ at time $t, \varepsilon_{t} n_{t} \sim N\left(0, s^{2} n_{t}\right)$ in the sense of Clark [1973]; Lamoureux and Lastrapes [1990]. Rational believers are speculative traders whose expectation from the market is zero because $E\left(\beta_{m} r_{m t} / n_{t}\right)=0$ in a market with rational believers. In the presence of rational believers, no heteroscedasticity and serial correlation could be observed. That is to say, the equity holders receive nothing from the market expectation as stock prices changes are assumed to be completely random and determined only by the number of stochastic (i.e. firm-specific) information events observed at the market on every corporate actions as price increments $P_{i t}-P_{i t-1}$ are subordinated to $\varepsilon_{t}$ and an increasing function of $t$ (see [Bachelier 2011]). As such, the mean of the market model as in equation 1 is of no use for speculators because the past patterns (as noted by [Mandelbrot 1963]) do not prevail in the future as expected. On the other hand, the model as in equation (1) will have zero or very low $r^{2}$ since this market is efficient (see [Tobin 1984; Roll 1988]). The following payoff table is given.

Figure 2 illustrates the characteristics of the market and the corresponding payoffs attributable to two types of players in the market. Heteroscedasticity and 


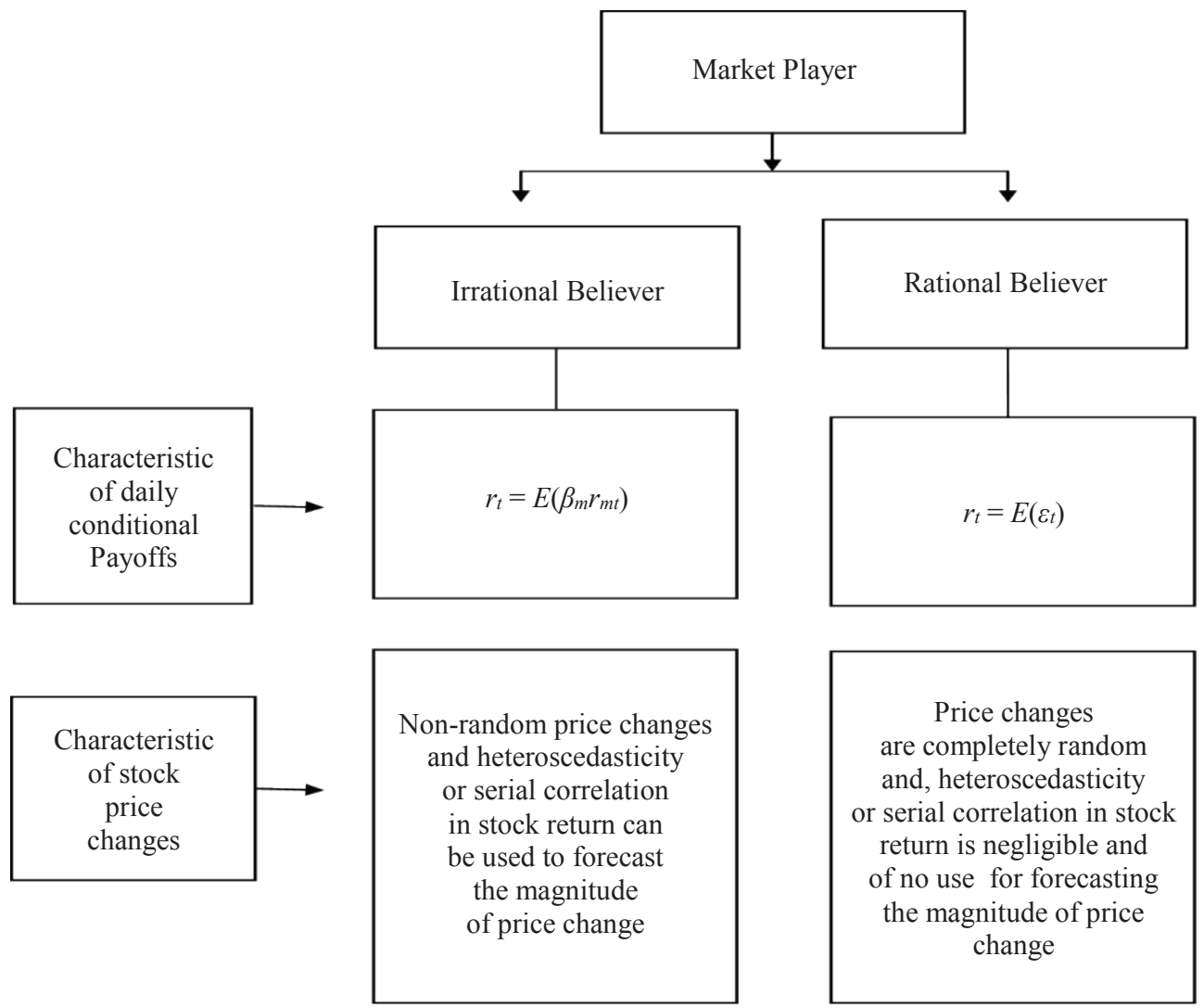

Fig. 2. The characteristics of stock market in the presence of rational and irrational believers

Source: author's presentation.

serial correlation in stock returns cannot be observed in efficient stock markets. In a market with rational believers, heteroscedasticity and serial correlation cannot be efficiently observed as each trade is carried out on firm-specific random information segments (events) and past records on price change patterns cannot be effectively used to forecast future price changes. On average, a player receives stochastic payoffs collected from all trades of a given day $\sum_{s=1}^{n_{t}} \delta_{s t}$ and mean $\beta_{0}+\beta_{m} r_{m t}$ conditional on firm-specific random information segments $n$ at operational time $t$ is zero as these players do not receive anything from the market expectation. In the presence of irrational believers, arbitrage opportunities are available in the market as large clusters of price changes reveal the pattern of stock price changes. Heteroscedasticity and serial correlation in return are apparent when there are large clusters of price changes (see [Mandelbrot 1963]). 


\subsection{Hypotheses of the study}

Under the null hypothesis, the religious population should belong to irrational believers who make irrational choices, and their economic decisions are based on personal beliefs rooted in common faith or beliefs and tend to form expectations based upon past records. As such, the equity markets in countries with this population are inefficient on average. If $H_{0}$ is accepted, the percentage of religiosity should be above $60 \%$ (this benchmark is in line with WIN-Gallup International's interpretations) and the atheist population should belong to the minority of the countries with inefficient stock markets.

An alternative hypothesis is that the religious population is rational and makes rational choices, decisions and view that the future is uncertain which is in the hands of God. If the religious population is rational, there should be no difference between religious and atheist population in terms of economic decision-making because the vast majority of scholars distinguish these two agents on the basis of "rationality" or "irrationality" in decision-making (see e.g. [Davis 1949; Evans-Pritchard 1965; Ellis 1980; Freud 2008]). Hence the stock markets in countries with these economic agents are efficient or converging towards efficiency. If $H_{1}$ is accepted, the percentage of religiosity should be below $60 \%$ and the atheist population should belong to the majority of the countries with efficient stock markets (or markets converging towards efficiency).

\section{Root causes of irrational behaviour}

\subsection{Poverty and lower level of education}

Poverty and education are highly correlated. Low-income economies have lower levels of education and vice versa (see [Rose, Dyer 2008; Hanushek et al. 2017]). Janjua and Kamal [2011] showed that education is the most significant contributor to poverty alleviation. The income level of a family determines the ability of the members to receive education. The causality between poverty and education can be precisely identified when an economy suffers from a crisis (e.g. [Nambissan 2010]). Maddox [2010] argued that poverty acts as a constraint in receiving a quality education. Disparities in income distribution also impact the differences in the quality of education, therefore low-income economies must have higher level of poverty than middle or high-income economies. The following figure illustrates the relationship between education and poverty. Poverty has a greater impact on primary and secondary levels of schooling where the basics of living are taught (see e.g. [Ferguson et al. 2007]). These instructions (taught in classroom) are essential for sorting out and dealing with matters of day-to-day life in a more logical manner. 


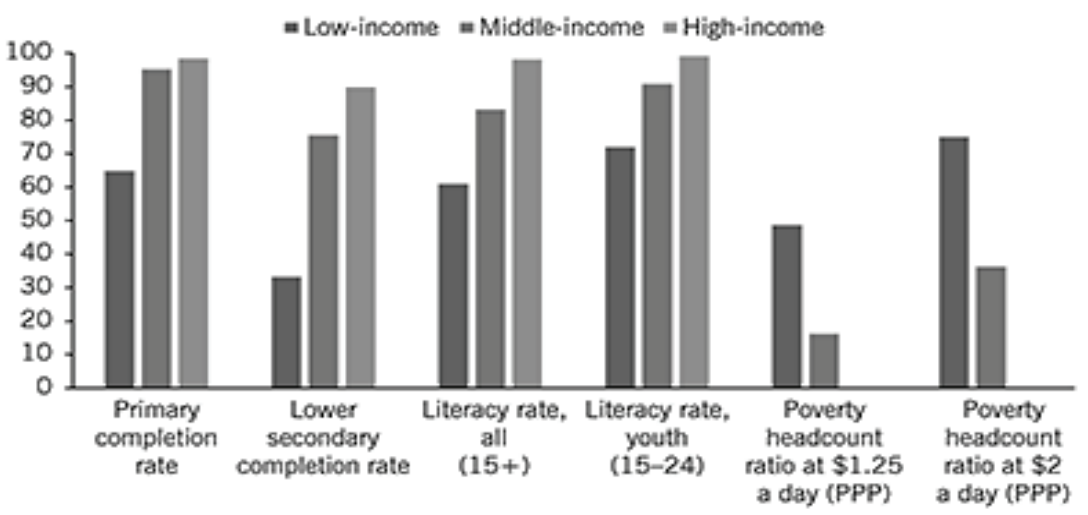

Fig. 3. Education, literacy and poverty vary across countries

Source: World Bank Development Indicators (2015).

The above figure shows that the primary education completion rate is low in lowincome countries whereas middle and high-income countries share almost the same but very high rate of completion. Somewhat similar facts can be observed for lower secondary education completion. Comparatively, a significant disparity is observed between low-income countries and high and middle-income countries (30\% to 90\%). High-income countries dominate, with the highest literacy rate in the age bracket of $15+$. The percentage applicable to low-income economies is at $65 \%$ which is the level somewhat similar to the primary education completion rate. Literacy rates of youth are higher for high-income countries and low and middle-income countries which have an acceptable level of literacy. However, a poverty headcount ratio at $\$ 1.25$ and $\$ 2$ a day is substantially high for low-income economies.

On the other hand, there is a negative relationship between the level of education and measures of religiosity [Albrecht and Heaton 1984]. However, McFarland et al. [2010] argued that the relationship between education and religiosity varies according to religious traditions. A recent work by Schieman [2011] stated that individuals with higher income are less likely to identify religion as important in decision-making. Using data from two national surveys of American adults, he also observed that educated people are less likely to attribute their religiousness to decision-making. The following figure compares the importance of religion in day-to-day life.

According to the figure, high school graduates say religion is very important in their day-to-day life, but fewer than half of college graduates $(46 \%)$ say this. A somewhat similar ratio is observed for the categories who say that they believe in God or pray daily. More importantly, $11 \%$ of college graduates identify themselves as atheists, whereas about $4 \%$ of high school level adults say that they are atheists. 


\section{Compared with others, fewer college graduates pray regularly, say religion very important in their lives}

\% of U.S. adults with each level of education who ...

\begin{tabular}{|c|c|c|c|c|}
\hline & $\begin{array}{l}\text {... say religion is } \\
\text { very important }\end{array}$ & $\begin{array}{l}\text {... believe in God } \\
\text { w/absolute certainty }\end{array}$ & $\begin{array}{l}\text {... say they } \\
\text { pray daily }\end{array}$ & $\begin{array}{l}\text {... identify as } \\
\text { atheist/agnostic }\end{array}$ \\
\hline College grad. & $46 \%$ & 55 & 50 & 11 \\
\hline Some college & $\mathbf{5 3} \%$ & 65 & 57 & 8 \\
\hline H.S. or less & $\mathbf{5 8} \%$ & 66 & 57 & 4 \\
\hline
\end{tabular}

Fig. 4. Education and religiosity

Source: 2014 U.S religious landscape study.

These findings offer a wide range of arguments. A lower level of family income restricts access to education, which ultimately results in a lack of rationality in day-to-day decision-making. Poorly educated people are likely to be more sensitive to religious beliefs and their decision-making is often biased towards their beliefs (see [Schieman 2011]).

\section{Testing for Efficient Market Hypothesis and atheism}

A large body of literature involves testing for stock market efficiency at country levels. The famous publication by Worthington and Higgs [2004] tested the European equity markets, namely Austria, Belgium, Denmark, Finland, France, Germany, Greece, Ireland, Italy, the Netherlands, Norway, Portugal, Spain, Sweden, Switzerland and the United Kingdom, and four emerging markets such as the Czech Republic, Hungary, Poland and Russia for efficiency. The findings suggest that more developed markets such as Germany, Ireland, Portugal, Sweden and the United Kingdom and only Hungary, as an emerging market, follow a random walk.

Groenewold [1997] found that the Statex Actuaries Index and the NZSE-40 Index follow a random walk and the evidence is consistent with weak-form efficiency. Shaker [2013] examined the random walk behaviour of Finnish and Swedish stock markets using the variance ratio test procedures in [Lo, MacKinlay 1988] and found no evidence for the presence of random walk in stock price changes. Borges [2010] examined France, Germany, the UK, Greece, Portugal and Spain's daily and monthly equity index changes for random walk behaviour and found that monthly returns of all the six countries are consistent with weak form efficiency. The randomness of daily index changes is rejected for Greece and Portugal.

The following table carries an extensive review of literature on testing for EMH, with reference to the findings of the Global Index of Religiosity and Atheism. 


\begin{tabular}{|c|c|c|c|c|c|c|c|c|c|c|c|c|c|c|}
\hline 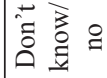 & $a$ & $0^{\circ}$ & in & ì & $\stackrel{2}{i}$ & $\therefore$ & $\stackrel{\text { Iे }}{ }$ & in & ฉ̊ & ¿े & 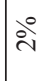 & iे & $\therefore$ & $\therefore$ \\
\hline 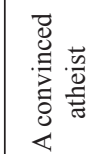 & $\infty$ & $\gtrless_{2}^{\circ}$ & $\stackrel{\circ}{\circ}$ & ठे & $\otimes_{\infty}^{\circ}$ & $\stackrel{\circ}{\circ}$ & ते & å & $\stackrel{\stackrel{2}{+}}{\stackrel{2}{\gamma}}$ & ले & 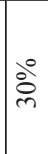 & ठํ & ते & in \\
\hline
\end{tabular}

\begin{tabular}{|c|c|c|c|c|c|c|c|c|c|c|c|c|c|c|}
\hline 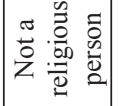 & - & ఏ̊ & 啇 & $\stackrel{\circ}{\stackrel{े}{+}}$ & 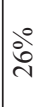 & $\stackrel{\circ}{\circ}$ & $\begin{array}{l}\stackrel{0}{0} \\
\stackrel{\sim}{\alpha}\end{array}$ & ठें & ठें & ํํํ & 商 & $\begin{array}{l}\stackrel{\circ}{\infty} \\
\text { ळ) }\end{array}$ & 总 & ले \\
\hline. & & 0 & ๖ீ & $\circ$ & $\therefore$ & $0^{\circ}$ & $0^{\circ}$ & $\circ$ & $0^{\circ}$ & 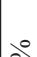 & $\AA^{0}$ & 0 & & \\
\hline
\end{tabular}

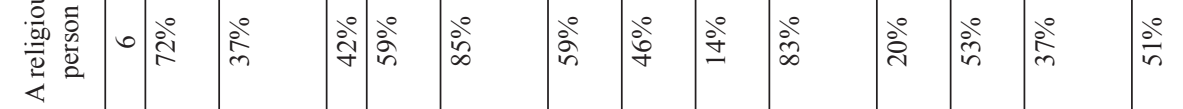

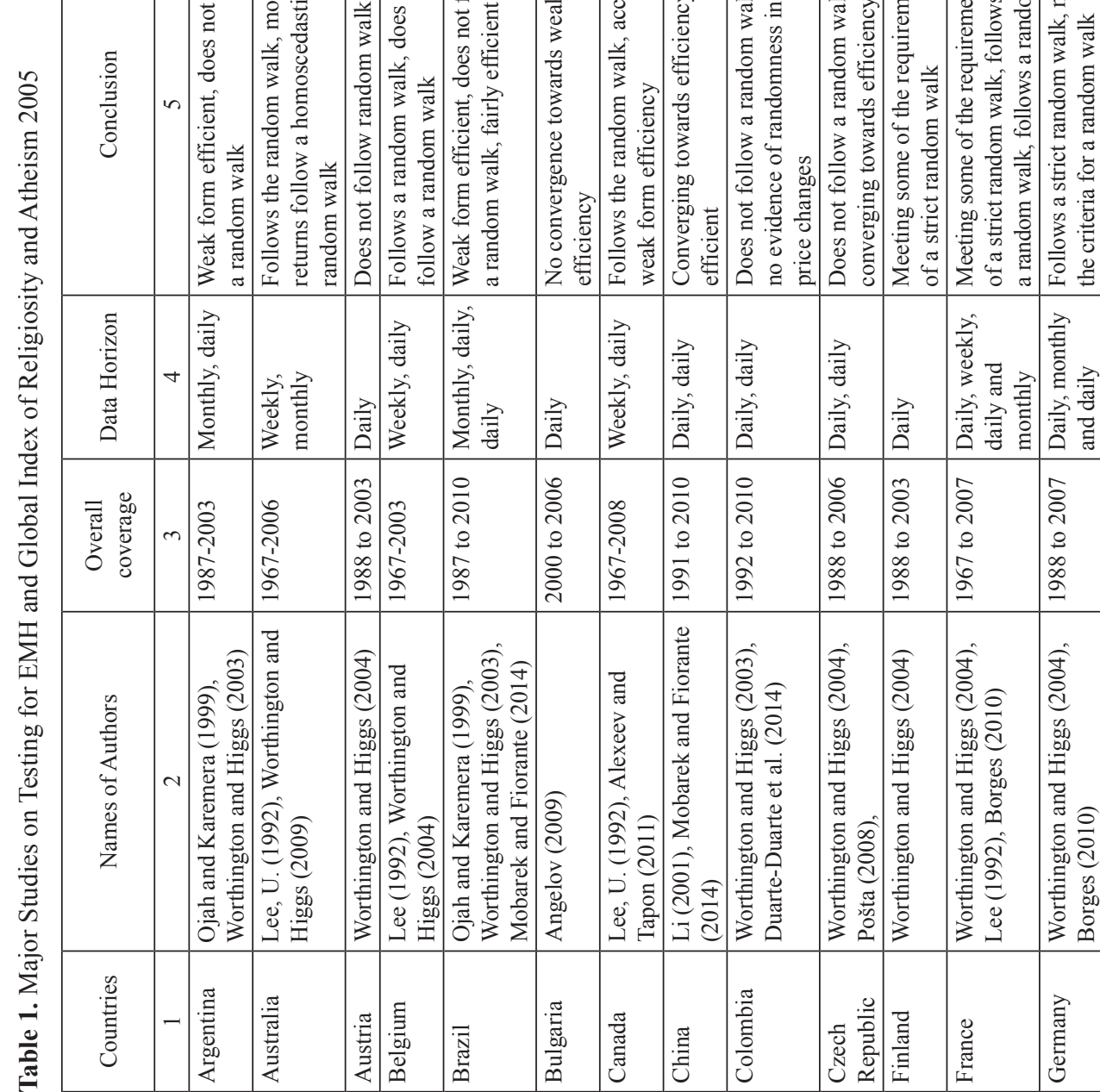




\begin{tabular}{|c|c|c|c|c|c|c|c|c|c|c|c|c|c|c|c|c|}
\hline$\therefore$ & $\stackrel{\circ}{\circ}$ & $\stackrel{\circ}{\circ}$ & ठ̊ & $\stackrel{\circ}{\circ}$ & तें & $\stackrel{\circ}{-}$ & $\stackrel{\circ}{\stackrel{0}{0}}$ & $\stackrel{\circ}{\circ}$ & $\stackrel{2}{\circ}$ & ठें & $\grave{1}^{\circ}$ & $\stackrel{\text { ஸे }}{ }$ & $\stackrel{\circ}{\circ}$ & $\dot{b}^{\circ}$ & $\stackrel{\circ}{\circ}$ & लें \\
\hline$\stackrel{\circ}{\circ}$ & ڤे & ले & 号 & $\stackrel{0}{\infty}$ & $\frac{\partial}{m}$ & $\stackrel{\text { iे }}{ }$ & i̊ & $\stackrel{\text { ڤे }}{ }$ & $\stackrel{\circ}{-}$ & $\dot{\theta}^{\circ}$ & in & $\stackrel{\stackrel{\circ}{ \pm}}{ }$ & $\stackrel{\circ}{-}^{\circ}$ & $\stackrel{\text { ஸे }}{ }$ & $\stackrel{\circ}{+}$ & लें \\
\hline$\stackrel{\text { Nे }}{\circ}$ & $\frac{\partial^{\circ}}{i n}$ & $\stackrel{\circ}{\check{m}}$ & 过 & i̊ & $\frac{\partial^{\circ}}{m}$ & ठํ & $\frac{\partial^{\circ}}{m}$ & 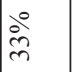 & ڤे̀ & $\stackrel{\circ}{\stackrel{0}{2}}$ & in & 六 & $\stackrel{\circ}{+}$ & $\stackrel{\infty}{\infty}$ & $\stackrel{\circ}{\stackrel{े}{ }}$ & 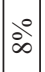 \\
\hline هั & $\begin{array}{l}\circ \\
\infty \\
\infty\end{array}$ & $\frac{\circ}{\infty}$ & 突 & $\stackrel{\text { }}{\stackrel{0}{\circ}}$ & $\stackrel{\circ}{0}$ & $\begin{array}{l}\stackrel{\circ}{\infty} \\
\infty\end{array}$ & 六 & 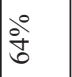 & ठั่ & $\frac{\partial^{\circ}}{\infty}$ & ळें & $\stackrel{\circ}{ซ}$ & ळें & 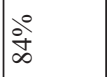 & iे & $\mid \begin{array}{l}0 \\
\dot{0} \\
\infty\end{array}$ \\
\hline 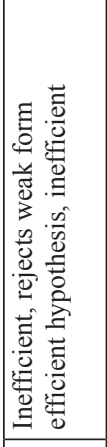 & 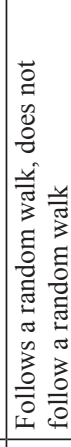 & 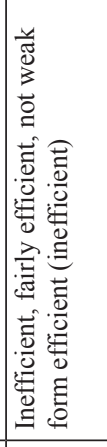 & 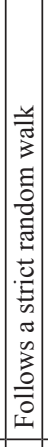 & 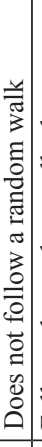 & 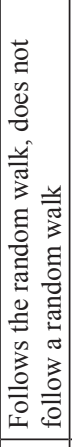 & 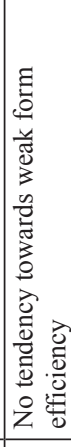 & 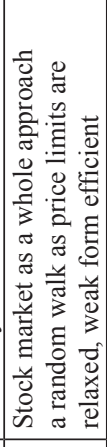 & 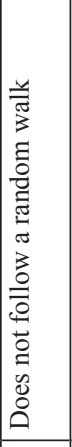 & 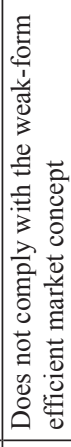 & 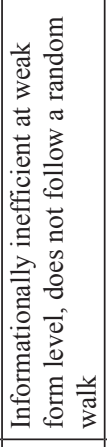 & & 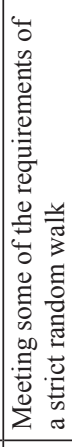 & 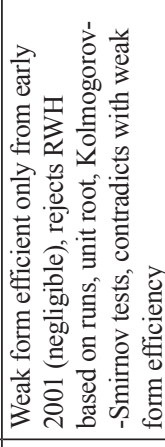 & 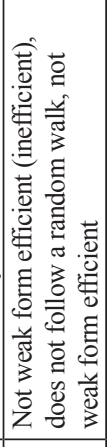 & 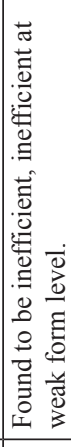 & 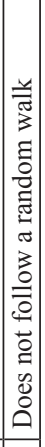 \\
\hline 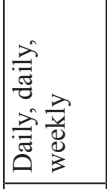 & 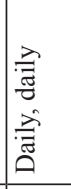 & 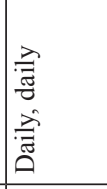 & $\begin{array}{l}\lambda \\
\overline{\bar{\Xi}} \\
\end{array}$ & : & 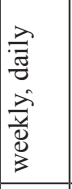 & 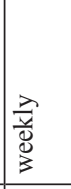 & 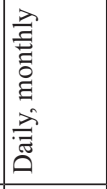 & 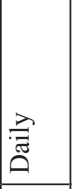 & $\begin{array}{l}\stackrel{x}{\overline{\tilde{J}}} \\
\underline{\Delta}\end{array}$ & 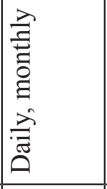 & & 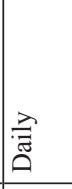 & 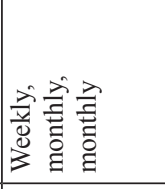 & 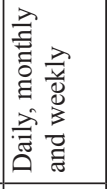 & 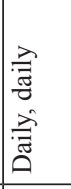 & $\begin{array}{l}\vec{\lambda} \\
\overline{\tilde{\Xi}} \\
\end{array}$ \\
\hline 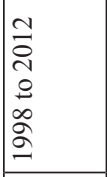 & 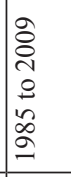 & 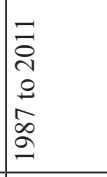 & 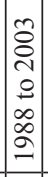 & 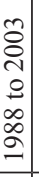 & 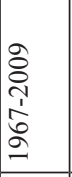 & 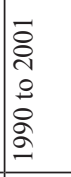 & 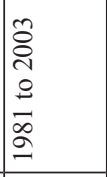 & 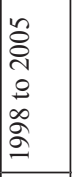 & 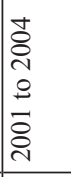 & 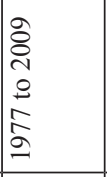 & & 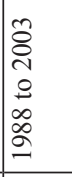 & 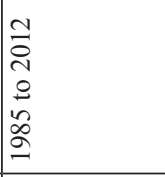 & 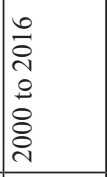 & 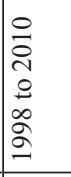 & 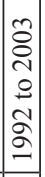 \\
\hline 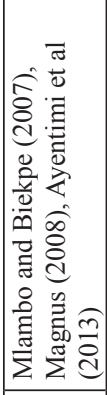 & 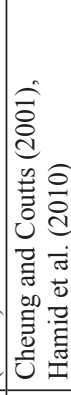 & 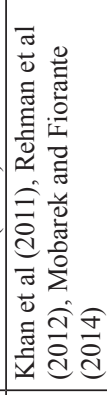 & 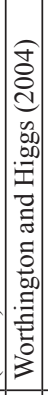 & 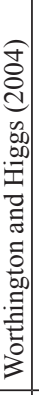 & 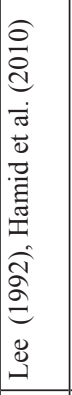 & 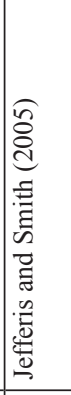 & 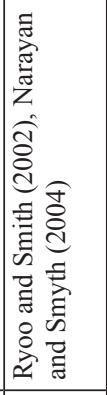 & 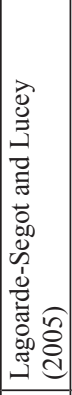 & 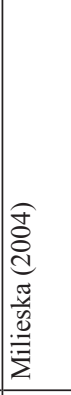 & 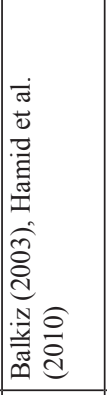 & & 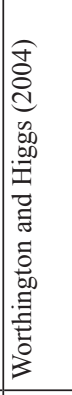 & 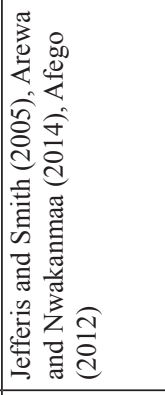 & 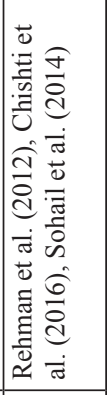 & 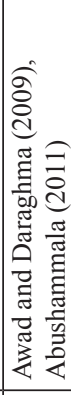 & 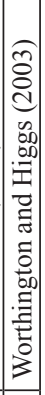 \\
\hline డ్ & 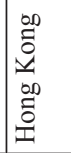 & 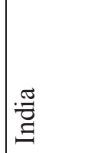 & 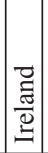 & 焉 & 总 & & 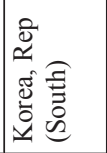 & 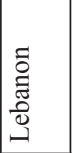 & 莺 & 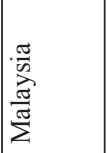 & & 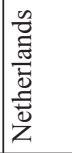 & 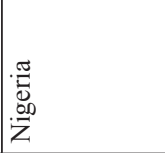 & 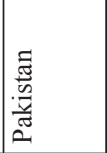 & 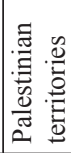 & \\
\hline
\end{tabular}




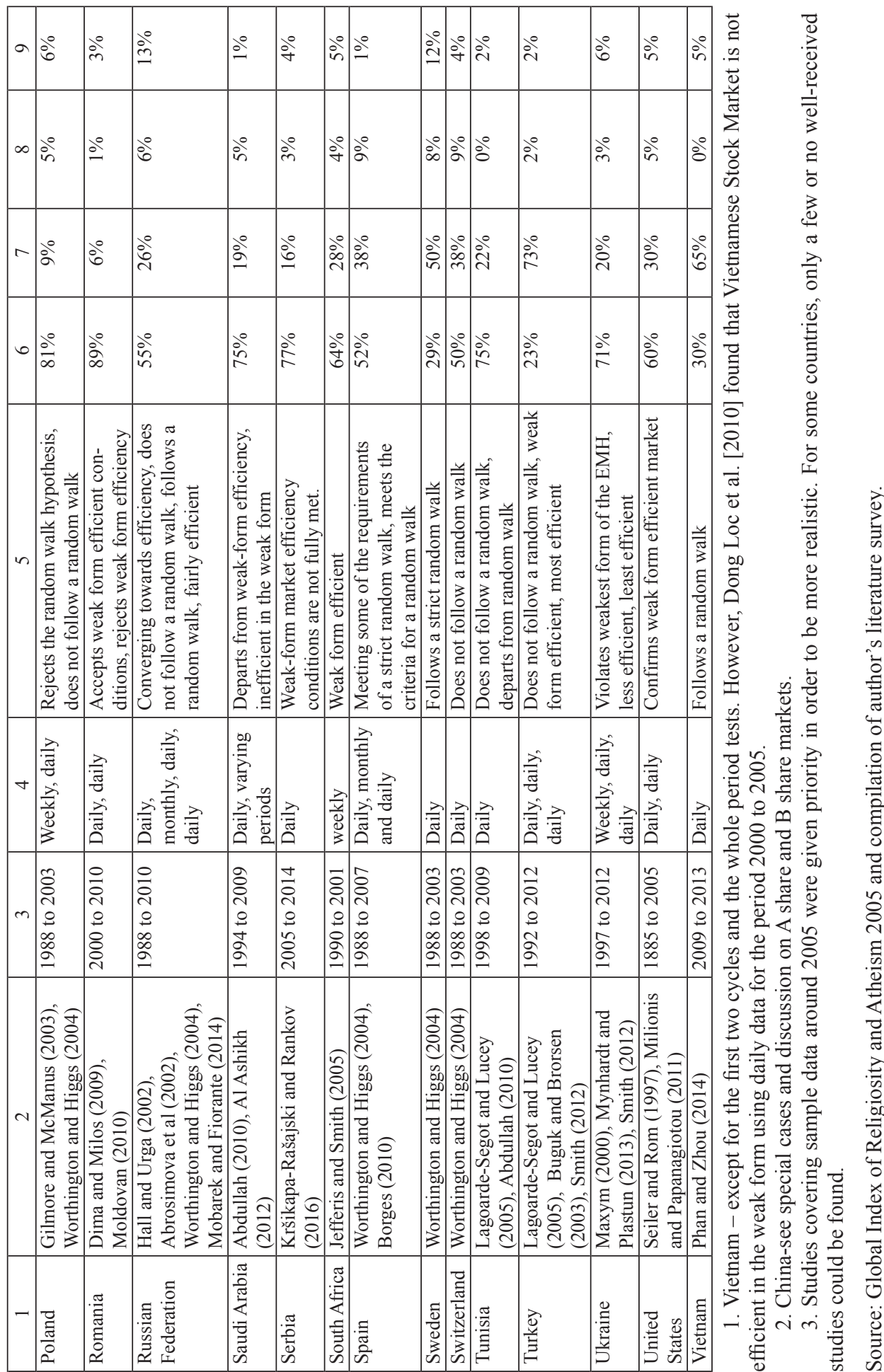


As per the summary of findings of the WIN-Gallup International, 59\% of the world's population could be placed under the category of religious person, whereas $23 \%$ of the population identify themselves as not religious, whilst $13 \%$ of the population are convinced atheists. When conditions of equity markets are identified against these findings, it uncovers interesting facts about the determinants of EMH. Following observation, it seems that almost all religious countries (as measured by the percentage score of more than $60 \%$ ) have inefficient or, if not, less efficient equity markets. The literature survey gives priority to major studies carried out during (or near) the period of the global poll, so that it justifies a more realistic comparison and evaluation. On the other hand, the Chinese A-share and B-share markets offer an avenue for researchers to test the impact of religiosity on stock market efficiency. B-shares are traded in foreign currencies on the Shanghai and Shenzhen stock exchanges. Trading in these shares was limited only to foreigners until 19 February 2001. Conversely, A-shares are nominated in Renminbi and are allowed to be traded only by local investors until the 2003 reform. Religiosity of China is $14 \%$, which can be attributed mainly to the local population. As such, testing EMH on A-share covering a sufficient sample period (but prior to February 2001) would provide prima facie evidence confirming the null hypothesis of this study. If the null hypothesis is supported by these observations, A-share market price changes or index changes should be random or converging towards efficiency, but B share market prices changes should not be consistent with the conditions of weak form efficiency or efficient markets. Lima and Tabak [2004] tested the A-share and B share markets for efficiency (1992 to 2000) using daily returns and found that only A-shares are efficient. Similar findings were reported by Fifield and Jetty [2008] for the period 1996 to 2005. Charles and Darné [2009] also found that daily price changes (1992 to 2007) of A-shares are efficient and B-class of shares does not follow the random walk hypothesis. These findings provide empirical support for the acceptance of the null hypothesis of this study.

\section{Conclusion}

The positive relationship between family income and education has been widely documented in recent literature [e.g. Blanden and Gregg 2004], and that educated people tend to be more rational in the course of economic decision-making [Moshman 1990]. As the literature survey points out, less educated adults tend to be more religious and bias economic decision-making towards their beliefs [Schieman 2011]. Conversely, more educated people often have an inquiring mind and tend to find answers with a logical reasoning, based on their knowledge and experience [see Chapell and Overton 2002]. Crudden and Barnes [2016] suggested that procedural and theoretical understanding through individuals' thought process play an important role in reasoning independent of their beliefs. This literature teaches one important principle about rationality and its ultimate outcome for being efficient in any form of 
economic activity. If an individual understands the logic of religion and the role of God, it is clear that the act of God is unknown, and forming expectations about the future outcome of the economic decisions made at present, in conjunction with beliefs, does not make sense.

As hypothesized, religious people are 'irrational believers' on average, and their economic actions are directed towards achieving future outcome are based on their expectations about the future. These believers, as economic agents, rely largely on past experiences, patterns and records, in forming the expectations about the future as their common behavioural trait. This is evidenced by the findings of the review and comparison made in Table 1. Almost all equity markets of countries dominated by religiosity are inefficient, or at least inefficient at weak form level. The form of stock market efficiency acts as a proxy variable for testing the null hypothesis of this study. The study reveals that religious believers, irrespective of differences in their religious beliefs or norms, are irrational as the null hypothesis of this study, is clearly accepted. The root causes of the inefficiency cannot be ignored. Poverty (level of family income) and level of education impact the religiosity. Low income level and poor education are the main courses of developing irrationality. One class of this mass irrational population is religious believers (i.e. irrational religious believers), whose behaviour may cause economy-wide consequences. The allocation of resources of an economy and its management may not be at the optimal level in the presence of these anomalies or externalities. As such, the policymakers should design and implement more robust policies and guidelines for poverty alleviation and the enrichment of education at country level.

\section{Acknowledgment}

I would like to thank the Editor-in-Chief, Professor Jacek Uchman andthe Managing Editor, Professor Ilona Fałat-Kilijańska. I would also like to thank the members of the editorial team for their friendly editorial assistance. This paper has been benefited from the constructive comments and suggestions of two anonymous reviewers. All remaining errors are my responsibility.

\section{References}

Abdmoulah W. (2010), Testing the evolving efficiency of Arab stock markets, International Review of Financial Analysis, vol. 19, no. 1, pp. 25-34.

Abrosimova N., Dissanaike G., Linowski D. (2002), Testing weak-form efficiency of the Russian stock market. In EFA 2002 Berlin Meetings Presented Paper, available online at https://papers.ssrn.com/ sol3/papers.cfm?abstract_id $=302287$.

Abushammala S.N. (2011), Testing the weak form efficiency of Palestine exchange, International Journal of Economics and Finance, vol. 3, no. 6, pp. 244-253.

Afego P. (2012), Weak form efficiency of the Nigerian stock market: An empirical analysis (1984-2009), International Journal of Economics and Financial Issues, vol. 2, no. 3, pp. 340-347. 
Al Ashikh A.I. (2012), Testing the weak-form of efficient market hypothesis and the day-of-the-week effect in Saudi stock exchange: Linear approach, International Review of Business Research Papers, vol. 8, no. 6, pp. 27-54.

Alawadhi A. (2016), Essays on religious beliefs and stock market outcomes, Doctoral Dissertation, RMIT University, available at https://core.ac.uk/download/pdf/83608136.pdf.

Albrecht S.L., Heaton T.B. (1984), Secularization, higher education, and religiosity, Review of Religious Research, vol. 26, no. 1, pp. 43-58.

Alexeev V., Tapon F. (2011), Testing weak form efficiency on the Toronto Stock Exchange, Journal of Empirical Finance, vol. 18, no. 4, pp. 661-691.

Angelov N. (2009), Testing the weak-form efficiency of the Bulgarian stock market, Discussion Paper, Bulgarian National Bank, available at https://www.bnb.bg/bnbweb/groups/public/documents/ bnb_publication/discussion_2009_71_en.pdf.

Arewa A., Nwakanmaa P.C. (2014), Re-validating weak-form hypothesis in the Nigerian capital market: A comparative test analyses, International Business Research, vol. 7, no. 4, pp. 73-83.

Audi R. (1991), Faith, belief, and rationality, Philosophical Perspectives, vol. 5, pp. 213-239.

Awad I. Daraghma Z., (2009), Testing the weak-form efficiency of the Palestinian securities market, International Research Journal of Finance and Economics, no. 32, pp. 7-17.

Ayentimi D.T., Mensah A.E., Naa-Idar F. (2013), Stock market efficiency of the Ghana stock exchange: An objective analysis, International Journal of Management, Economics and Social Sciences, vol. 2, no. 2, pp. 54-75.

Bachelier L. (2011), Louis Bachelier's theory of speculation: the origins of modern finance, Princeton University Press available at https://books.google.com/books?hl=en\&lr=\&id=XcZwuHGRxsgC\& oi $=$ fnd\&pg $=$ PR7\&dq $=$ Louis + Bachelier $\% 27 \mathrm{~s}+$ theory + of + speculation: + the + origins + of + modern + finance\&ots=6jAUL_1AKQ\&sig=2QfU6-Jj-PYczD-50UUiqwrpf0Y.

Balkiz O. (2003), Testing informational market efficiency on Kuala Lumpur stock exchange, Journal Ekonomi Malaysia, Vol. 37, pp. 3-20.

Banz R.W. (1981), The relationship between return and market value of common stocks, Journal of Financial Economics, vol. 9, no. 1, pp. 3-18.

Basu S. (1977), Investment performance of common stocks in relation to their price earnings ratios: A test of the efficient market hypothesis, Journal of Finance, vol. 32, no. 3, pp. 663-682.

Bible in One Year (2017), God's plans for your future, Commentary, available at https://www.bibleinoneyear.org/bioy/commentary/1034.

Blanden J., Gregg P. (2004), Family income and educational attainment: a review of approaches and evidence for Britain, Oxford Review of Economic Policy, vol. 20, no. 2, pp. 245-263.

Blau B.M. (2017), Religiosity and the volatility of stock prices: A cross-country analysis, Journal of Business Ethics, vol. 144, no. 3, pp. 609-621.

Blau B.M. (2018), Does religiosity affect liquidity in financial markets?, Journal of Behavioral and Experimental Finance, vol. 19, pp. 72-83.

Block L., Kramer T. (2009), The effect of superstitious beliefs on performance expectations, Journal of the Academy of Marketing Science, vol. 37, no. 2, pp. 161-169.

Borges M.R. (2010), Efficient market hypothesis in European stock markets, European Journal of Finance, vol. 16, no. 7, pp. 711-726.

Brams S.J. (1979), Faith versus rationality in the Bible: game-theoretic interpretations of sacrifice in the Old Testament, Applied Game Theory, Physica, Heidelberg, pp. 430-445.

Buguk C., Brorsen B.W. (2003), Testing weak-form market efficiency: Evidence from the Istanbul Stock Exchange, International Review of Financial Analysis, vol. 12, no. 5, pp. 579-590.

Chang E.C., Cheng J.W., Khorana A. (2000), An examination of herd behavior in equity markets: An international perspective, Journal of Banking Finance, vol. 24, no. 10, pp. 1651-1679.

Chapell M.S., Overton W.F. (2002), Development of logical reasoning and the school performance of African American adolescents in relation to socioeconomic status, ethnic identity, and self-esteem, Journal of Black Psychology, vol. 28, no. 4, pp. 295-317. 
Charles A., Darné O. (2009), The random walk hypothesis for Chinese stock markets: Evidence from variance ratio tests, Economic Systems, vol. 33, no. 2, pp. 117-126.

Cheung K.C., Andrew Coutts J. (2001), A note on weak form market efficiency in security prices: Evidence from the Hong Kong stock exchange, Applied Economics Letters, vol. 8, no. 6, pp. 407-410.

Chishti M.F., Chaudhry A.F., Afzal A. (2016), Testing the efficiency of Pakistani stock market (psx): a case of kse-100 index, Gomal University Journal of Research, no. 4, pp. 13-19.

Christie P., Gordon A. (1992), Politics, poverty and education in rural South Africa, British Journal of Sociology of Education, vol. 13, no. 4, pp. 399-418.

Cuong P.K., Jian Z. (2014), Factors influencing individual investors' behavior: An empirical study of the Vietnamese stock market, American Journal of Business and Management, vol. 3, no. 2, pp. 77-94.

Davis, K. (1949), Human society, Macmillan, New York

De Long J.B., Shleifer A., Summers L.H., Waldmann R.J. (1990), Positive feedback investment strategies and destabilizing rational speculation, Journal of Finance, vol. 45, no. 2, pp. 379-395.

Dima B., Milos L.R. (2009), Testing the efficiency market hypothesis for the Romanian stock market, Annales Universitatis Apulensis: Series Oeconomica, vol. 11, no. 1, pp. 402-415.

Dong Loc T., Lanjouw G., Lensink R. (2010), Stock-market efficiency in thin-trading markets: the case of the Vietnamese stock market, Applied Economics, vol. 42, no. 27, pp. 3519-3532.

Duarte-Duarte J.B., Pérez-Iñigo M., Manuel J., Sierra-Suárez K.J. (2014), Testing the efficiency market hypothesis for the Colombian stock market, Dyna, vol. 81, no. 185, pp. 100-106.

Ellis A. (1980). Psychotherapy and atheistic values: A response to AE Bergin's Psychotherapy and religious values, Journal of Counseling and Clinical Psychology, vol. 48, pp. 635-639.

Emerson R., Hall S.G., Zalewska-Mitura A. (1997), Evolving market efficiency with an application to some Bulgarian shares, Economics of Planning, vol. 30, no. 2-3, pp. 75-90.

Evans-Pritchard E.E. (1965), Theories of primitive religion, Oxford University Press.

Fama E.F. (1965), The behavior of stock-market prices, Journal of Business, vol. 38, no. 1, pp. 34-105.

Ferguson H.B., Bovaird S., Mueller M.P. (2007), The impact of poverty on educational outcomes for children, Paediatrics Child Health, vol. 12, no. 8, pp. 701-706.

Fifield G.M., Jetty J. (2008), Further evidence on the efficiency of the Chinese stock markets: A note, Research in International Business and Finance, vol. 22, pp. 351-361.

Freud S. (2008), The future of an illusion, vol. 55, Penguin UK.

Gilmore C.G., McManus G.M. (2003), Random-walk and efficiency tests of Central European equity markets, Managerial Finance, vol. 29, no. 4, pp. 42-61.

Groenewold N. (1997), Share market efficiency: tests using daily data for Australia and New Zealand, Applied Financial Economics, vol. 7, no. 6, pp. 645-657.

Groenewold N., Kang K.C. (1993), The semi strong efficiency of the Australian share market, Economic Record, Vol. 69, no. 4, pp. 405-410.

Grullon G., Kanatas G., Weston J., (2009), Religion and corporate (mis) behavior, Working Paper, Rice University, available at http://www.ruf.rice.edu/ westonj/wp/Religion.pdf.

Hall S., Urga G. (2002), Testing for ongoing efficiency in the Russian stock market, Emerging Markets Group, Discussion Paper, available at https://scholar.google.com/scholar?hl=en\&as_sdt=0\%2C5$\& \mathrm{q}=$ Testing + for + ongoing + efficiency + in + the + Russian + stock + market\&btnG $=$.

Hamid K., Suleman M.T., Ali Shah S.Z., Akas I., Shahid R. (2017), Testing the weak form of efficient market hypothesis: Empirical evidence from Asia-Pacific markets, International Research Journal of Finance and Economics, vol. 58, pp. 121-133.

Hanushek E.A., Schwerdt G., Woessmann L., Zhang L. (2017), General education, vocational education, and labor-market outcomes over the lifecycle, Journal of Human Resources, vol. 52, no. 1, pp. 48-87.

Hawking S. (2004), The science of second-guessing, New York Times magazine interview, December 12, 2004, available at https://www.nytimes.com/2004/12/12/magazine/the-science-of-secondguessing.html.

Homayouni A. (2011), The role of personality traits and religious beliefs in tendency to addiction, Procedia-Social and Behavioral Sciences, vol. 30, pp. 851-855. 
Iannaccone L.R. (1997), Rational choice: Framework for the scientific study of religion, [in:] Rational Choice Theory and Religion: Summary and Assessment, ed. L.A. Young, Routledge, New York, pp. 25-42.

Jamal M., Badawi J. (1993), Job stress among Muslim immigrants in North America: Moderating effects of religiosity, Stress and Health, vol. 9, no. 3, pp. 145-151.

Janjua P.Z., Kamal U.A. (2011), The role of education and income in poverty alleviation: A cross-country analysis, Lahore Journal of Economics, vol. 16, no. 1, 143-172.

Jefferis K., Smith G. (2005), The changing efficiency of African stock markets, South African Journal of Economics, vol. 73, no. 1, pp. 54-67.

Keynes J.M. (1937), The general theory of employment, Quarterly Journal of Economics, vol. 51, no. 2, pp. 209-223.

Khan A.Q., Ikram S., Mehtab M. (2011), Testing weak form market efficiency of Indian capital market: A case of national stock exchange (NSE) and Bombay stock exchange (BSE), African Journal of Marketing Management, Vol. 3, no. 6, pp. 115-127.

Khoynezhad G., Rajaei A.R., Sarvarazemy A. (2012), Basic religious beliefs and personality traits, Iranian Journal of Psychiatry, vol. 7, no. 2, pp. 82-86.

Kršikapa-Rašajski J., Rankov S.G. (2016), Testing weak form efficiency on the capital markets in Serbia, Megatrend Revija, vol. 13, no. 1, pp. 265-278.

Lagoarde-Segot T., Lucey B.M. (2005), Stock market predictability in the MENA: evidence from new variance ratio tests and technical trade analysis, Discussion Paper, Trinity College Dublin, available at https://www.tcd.ie/triss/assets/PDFs/iiis/iiisdp92.pdf.

Lee U. (1992), Do stock prices follow random walk?: Some international evidence, International Review of Economics and Finance, vol. 1, no. 4, pp. 315-327.

Li X. (2001), China's evolving stock market efficiency reconsidered: The Kalman filter analysis, Working Paper, Massey University, available at https://papers.ssrn.com/sol3/papers.cfm?abstract $\mathrm{id}=961108$.

Lima E.J.A., Tabak B.M. (2004), Tests of the random walk hypothesis for equity markets: Evidence from China, Hong Kong and Singapore, Applied Economics Letters, vol. 11, no. 4, pp. 255-258.

Lo A.W., MacKinlay A.C. (1988), Stock market prices do not follow random walks: Evidence from a simple specification test, Review of Financial Studies, vol. 1, no. 1, pp. 41-66.

Lo A.W., MacKinlay, A.C. (1989), The size and power of the variance ratio test in finite samples: A Monte Carlo investigation, Journal of Econometrics, vol. 40, no. 2, pp. 203-238.

Maddox B. (2010), Marginal returns: rethinking mobility and educational benefit in contexts of chronic poverty, Compare, vol. 40, no. 2, pp. 213-222.

Magnus F.J. (2008), Capital market efficiency: An analysis of weak-form efficiency on the Ghana Stock Exchange, Journal of Money, Investment and Banking, vol. 5, no. 5, pp. 5-13.

Malkiel B.G. (1995), Returns from investing in equity mutual funds 1971 to 1991, Journal of Finance, Vol. 50, no. 2, pp. 549-572.

Malkiel B.G. (2003), The efficient market hypothesis and its critics, Journal of Economic Perspectives, vol. 17 , no. 1 , pp. 59-82.

Malkiel B.G., McCue K. (1985), A random walk down Wall Street, vol. 8, Norton, New York.

Mandelbrot B.B. (1963), The variation of certain speculative prices, Journal of Business, vol. 36, no. 4, pp. 394-419.

Maxym D. (2000), The efficient market hypothesis and the Ukrainian stock market, Master's Thesis, National University of Kyiv-Mohyla Academy, available at http://www.kse.org.ua/uploads/file/ library/2000/Dedov.pdf.

McCrudden M.T., Barnes A. (2016), Differences in student reasoning about belief-relevant arguments: a mixed methods study, Metacognition and Learning, vol. 11, no. 3, pp. 275-303.

McDaniel S.W., Burnett J.J. (1990), Consumer religiosity and retail store evaluative criteria, Journal of the Academy of Marketing Science, vol. 18, no. 2, pp. 101-112. 
McFarland M.J., Wright B.R., Weakliem D.L. (2010), Educational attainment and religiosity: Exploring variations by religious tradition, Sociology of Religion, vol. 72, no. 2, pp. 166-188.

McGuire S.T., Omer T.C., Sharp N.Y. (2011), The impact of religion on financial reporting irregularities, The Accounting Review, vol. 87, no. 2, pp. 645-673.

Milieska G. (2004), The evaluation of the Lithuanian stock market with the weak-form market efficiency hypothesis, Østfold University College, Halden Norway, Spring.

Milionis A.E., Papanagiotou E. (2011), A test of significance of the predictive power of the moving average trading rule of technical analysis based on sensitivity analysis: application to the NYSE, the Athens Stock Exchange and the Vienna Stock Exchange, Implications for weak-form market efficiency testing, Applied Financial Economics, vol. 21, no. 6, pp. 421-436.

Mlambo C., Biekpe N. (2007), The efficient market hypothesis: Evidence from ten African stock markets, Investment Analysts Journal, vol. 36, no. 66, pp. 5-17.

Mobarek A., Fiorante A. (2014), The prospects of BRIC countries: Testing weak-form market efficien$c y$, Research in International Business and Finance, vol. 30, pp. 217-232.

Moldovan D. (2010), Testing the efficiency of the Romanian stock market. Development, Energy, Environment, Economics, pp. 378-381.

Moltafet G., Mazidi M., Sadati S. (2010), Personality traits, religious orientation and happiness, Procedia-Social and Behavioral Sciences, vol. 9, pp. 63-69.

Moshman, D. (1990), Rationality as a goal of education, Educational Psychology Review, vol. 2, no. 4, pp. 335-364.

Mynhardt R.H., Plastun A. (2013), The overreaction hypothesis: The case of Ukrainian stock market, Corporate Ownership Control, vol. 11, no. 1, pp. 406-422.

Nambissan G.B. (2010), The global economic crisis, poverty and education: a perspective from India, Journal of Education Policy, vol. 25, no. 6, pp. 729-737.

Narayan P.K., Smyth R. (2004), Is South Korea's stock market efficient?, Applied Economics Letters, vol. 11, no. 11, pp. 707-710.

Ojah K., Karemera D. (1999), Random walks and market efficiency tests of Latin American emerging equity markets: a revisit, Financial Review, vol. 34, no. 2, pp. 57-72.

Phan K.C., Zhou J. (2014), Market efficiency in emerging stock markets: A case study of the Vietnamese stock market, IOSR Journal of Business and Management, vol. 16, no. 4, 61-73.

Pošta V. (2008), Estimating the dynamics of weak efficiency on the Prague stock exchange using the Kalman filter, Czech Journal of Economics and Finance (Finance a uver), vol. 58, no. 05-06, pp. 248-260.

Rehman A.U., Masood M., Arshed S., Shah S.Z.A. (2012), Evaluation of weak form of efficiency: an empirical study of emerging south Asian stock markets, International Research Journal of Finance and Economics, vol. 88, pp. 124-131.

Roll R. (1988), R2, Journal of Finance, vol. 43, no. 3, pp. 541-566.

Rose P., Dyer C. (2008), Chronic poverty and education: a review of literature, Working Paper, Chronic Poverty Research Centre, available at https://papers.ssrn.com/sol3/papers.cfm?abstract_ id $=1537105$.

Ryoo H.J., Smith G. (2002), Korean stock prices under price limits: Variance ratio tests of random walks, Applied Financial Economics, vol. 12, no. 8, pp. 545-553.

Schieman S. (2011), Education and the importance of religion in decision making: Do other dimensions of religiousness matter?, Journal for the Scientific Study of Religion, vol. 50, no. 3, pp. 570-587.

Schneider H., Krieger J., Bayraktar A. (2011), The impact of intrinsic religiosity on consumers' ethical beliefs: Does it depend on the type of religion? A comparison of Christian and Moslem consumers in Germany and Turkey, Journal of Business Ethics, vol. 102, no. 2, pp. 319-332.

Scudder E. (1897), Seeking after god, The Wesleyan-Methodist Magazine, vol. 120, pp. 426-426.

Seiler M.J., Rom W. (1997), A historical analysis of market efficiency: Do historical returns follow a random walk?, Journal of Financial and Strategic Decisions, vol. 10, no. 2, pp. 49-57. 
Shaker A.T. (2013), Testing the weak-form efficiency of the Finnish and Swedish stock market, European Journal of Business and Social Sciences, Vol. 2, no. 9, pp. 176-185.

Shiller R.C. (2000), Irrational exuberance, Philosophy Public Policy Quarterly, vol. 20, no. 1, pp. 18-23.

Shiller R.J., Fischer S., Friedman B.M. (1984), Stock prices and social dynamics, Brookings Papers on Economic Activity, vol. 1984, no. 2, pp. 457-510.

Smith G. (2012), The changing and relative efficiency of European emerging stock markets, The European Journal of Finance, vol. 18, no. 8, pp. 689-708.

Sohail A., Murtaza G., Habib Q., Azeem M. (2014), Efficiency of south Asian capital markets: an empirical analysis, European Journal of Business and Management, vol. 6, no. 11, pp. 30-33.

Tobin J. (1984), On the efficiency of the financial system, Lloyd's Banking Review, vol. 153, pp. 1-15.

Trueman B. (1994), Analyst forecasts and herding behavior. The Review of Financial Studies, vol. 7, no. 1, pp. 97-124.

Van Biema D., Chu J. (2006), Does God want you to be rich?, Time Magazine, available at http://content.time.com/time/magazine/article/0,9171,1533448,00.html.

Vitell S.J., Paolillo J.G. (2003), Consumer ethics: The role of religiosity, Journal of Business Ethics, Vol. 46, no. 2, pp. 151-162.

Weaver G.R., Agle B.R. (2002), Religiosity and ethical behavior in organizations: A symbolic interactionist perspective, Academy of Management Review, vol. 27, no. 1, pp. 77-97.

Wilson E. (1975): Sociobiology: The new synthesis. Cambridge, MA: Belknap Press of Harvard University Press.

Worthington A.C., Higgs H. (2003), Tests of random walks and market efficiency in Latin American stock markets: An empirical note, Discussion Paper, available at http://eprints.qut.edu.au/328/.

Worthington A.C., Higgs H. (2004), Random walks and market efficiency in European equity markets, Global Journal of Finance and Economics, vol. 1, no.1, pp. 59-78.

Worthington A.C., Higgs H. (2009), Efficiency in the Australian stock market, 1875-2006: a note on extreme long-run random walk behaviour, Applied Economics Letters, Vol. 16, no. 3, pp. 301-306.

\section{CZY LUDZIE RELIGIJNI SĄ IRRACJONALNI: BEZPOŚREDNI TEST Z EFEKTYWNEJ HIPOTEZY RYNKOWEJ}

Streszczenie: Współczesna literatura nie oferuje ilościowego testu irracjonalnego zachowania ludzi, zwłaszcza biorąc pod uwagę nieracjonalność w odniesieniu do działalności gospodarczej. Artykuł analizuje rolę ludzi wierzących w prowadzeniu działalności gospodarczej. Forma efektywności rynku akcji została przyjęta jako przybliżenie do przetestowania zerowej hipotezy mówiącej, że wierzący są przeciętnie irracjonalni. Rezultaty badań sugerują, że rynki akcji w krajach religijnych są nieefektywne na poziomie „słabej formy”. Dostarcza to dowodów prima facie na hipotezę, że wierzący są przeciętnie irracjonalni. W związku z tym zmiany cen akcji na tych rynkach papierów wartościowych można prognozować na podstawie wcześniejszych wzorców. Niski poziom dochodów i słabe wykształcenie są głównymi przyczynami rozwoju irracjonalności. Ponieważ irracjonalność skutkuje kosztami dla gospodarki, decydenci powinni opracować i wdrożyć bardziej solidne polityki i wytyczne dotyczące zmniejszania ubóstwa i wzbogacania edukacji na poziomie kraju.

Słowa kluczowe: religia, wierzący, skuteczna hipoteza rynkowa (EMH), ateiści, irracjonalność, edukacja. 